\title{
INFLUENCE OF PLASMAPHERESIS ON ANTI-OVARIAN ANTIBODIES LEVEL BEFORE IN VITRO FERTILIZATION IN WOMEN WITH INFERTILITY
}

\author{
Oksana V. BAKUN ${ }^{1 凶}$, Svitlana Y. KARATIEIEVA ${ }^{1}$, Svitlana B. SEMENENKO ${ }^{1}$, \\ Oksana I. YURKIV ${ }^{1}$, Ksenia V. SLOBODIAN ${ }^{1}$ \\ ${ }^{1}$ Higher State Educational Institution of Ukraine „Bukovinian State Medical University“, Chernivtsi, \\ Ukraine
}

Received 09 Apr 2018, Corrections received 14 July 2018, Accepted 24 Oct 2018

https://doi.org/10.31688/ABMU.2018.53.4.12

\section{Abstract}

Introduction. The study of anti-ovarian autoantibodies in patients with ovarian insufficiency against the background of normal levels of gonadotropins, prolactin and androgens shows that the incidence of autoimmune oophoritis among such women varies from $19.2 \%$ to $31.5 \%$.

The objective of the study was to study the anti-ovarian antibodies level in infertile women at the preparatory stage for in vitro fertilization.

Materials and methods. We examined 30 women, who were divided into the following groups: control group - 10 reproductively healthy women, who had a birth in the history (from 1 to 3); study group - 20 women with infertility of tube origin, who were included in the in vitro fertilization program. The study was performed between 2015-2017 in the Bukovinian State Medical University and Centre of Reproductive Medicine, Ukraine. The women signed the informed consent.

Results. The anti-ovarian antibodies level in infertile women was found out to be 1.7 times less than in the control group. Reduction of the level of anti-ovarian antibodies in patients from the study group was marked by the obstetric and gynecological history.
\end{abstract}

\section{Résumé}

L'influence de la plasmaphérèse sur le niveau d'anticorps anti-ovariens chez les femmes stériles pendant la phase préparatoire de la fécondation in vitro

Introduction. L'étude d'auto-anticorps anti-ovariens $(\mathrm{AAO})$ chez les patients avec insuffisance ovarienne dans le contexte des niveaux normaux de gonadotrophine, de la prolactine et des androgènes montre que l'incidence d'ovarite auto-immunisée parmi de telles femmes varie de $19,2 \%$ à $31,5 \%$.

Les matériaux et les procédés. Nous avons examiné 30 femmes qui ont été divisées dans les groupes suivants: le groupe de contrôle - 10 femmes en bonne santé reproductive avec une naissance dans l'histoire (de 1 à 3); le groupe principal - 20 femmes avec infertilité d'origine tubaire, qui ont été incluses dans le programme de fécondation in vitro.

Résultats. Le niveau d'AAO parmi les femmes infertiles s'est révélé être 1,7 fois moins élevé que dans le groupe de contrôle. La réduction du niveau d'anticorps anti-ovariens chez les patients du groupe principal a été marquée par les antécédents obstétrique et gynécologique . 
Conclusions. Anti-ovarian antibodies are present in both reproductively healthy women and in patients with infertility. The level of anti-ovarian antibodies can be both increased and reduced, depending on the pathological process that caused infertility. In both cases, this fact can testify the infertility. After plasmapheresis, the increased level of anti-ovarian antibodies sharply decreases.

Keywords: anti-ovarian antibodies, infertility, in vitro impregnation.

\section{INTRODUCTION}

The autoantibodies do not appear in a normal organism, since there is a danger of uncontrolled self-destruction of its own tissues, without obvious causes, and even its complete death ${ }^{1-3}$. Therefore, the appearance of antibodies against the own antigens is blocked $^{4,5}$. However, in some situations, the autoantibodies may have a physiological role $\mathrm{e}^{6-8}$. The appearance of antibodies against the damaged tissues may have (in some degree) a sanogenic role, since it allows them to be removed more quickly from the body ${ }^{9-11}$.

Natural autoantibodies in healthy individuals may also be specific autoantibodies in autoimmune diseases. According to some authors, such „healthy“ individuals, in whom the autoantibodies are detected, are sooner or later candidates for the appearance of the corresponding autoimmune diseases, since the latter manifest themselves only after accumulation of a certain critical number of antibodies, in accordance with the law of the transfer of quantity in quality ${ }^{12-14}$.

Anti-ovarian antibodies (AOA) damage various ovarian structures, including cell surfaces of the skin, yellow body, oocytes (eggs) and separate cells in the interstitial ovaries. Autoimmune oophoritis with lymphocytic infiltrates, cystic and atresia of follicles have been described ${ }^{15-18}$. Anti-ovarian antibodies are found in $22.7 \%$ of women with primary infertility and $37.5 \%$ with secondary infertility included in the program of extracorporal fertilization ${ }^{19-23}$.

Some authors pointed to the association of anti-ovarian antibodies with endometriosis and subsequent failures with implantation of embryos. Anti-ovarian antibodies may appear during intracorporal fertilization programs, as a result of repeated hormonal stimulation and microarray of ovaries when extracting oocytes ${ }^{24-28}$. The study of anti-ovarian autoantibodies in patients with ovarian insufficiency against the background of normal levels of gonadotropins, prolactin and androgens, shows that
Conclusions. Les anticorps anti-ovariens sont présents chez les femmes en bonne santé reproductive et chez les patientes infertiles. Le niveau d'anticorps anti-ovariens peut-être à la fois augmenté et réduit, en fonction du processus pathologique, qui a causé l'infertilité. Et dans les deux cas ce fait peut témoigner l'infertilité. Après la plasmaphérèse, un taux élevé d'anticorps anti-ovariens diminue fortement, indiquant son efficacité et la possibilité d'utilisation dans le programme pour la préparation in vitro.

Mots-clés: anticorps anti-ovariens, infertilité, fécondation in vitro.

the incidence of autoimmune oophoritis among such women varies from $19.2 \%$ to $31.5 \%{ }^{29.35}$.

The OBJeCtive OF THE STUDY was the determination of anti-ovarian antibodies level in infertile women, at the preparatory stage for in vitro fertilization.

\section{Materials ANd Methods}

We examined 30 women, who were divided into the following groups:

- Control group - 10 reproductively healthy women, who had a birth in the history (from 1 to 3 ).

- Study group - 20 women with infertility of tube origin, were included in the in vitro fertilization program.

The study was performed in Bukovinian State Medical University and Centre of Reproductive Medicine, Ukraine, between 2015-2017.

Along with the definition of anti-ovarian antibodies, the determination of hormonal homeostasis, indicators of nonspecific and specific immune defense, ultrasound of the pelvic organs, were performed.

The determination of anti-ovarian antibodies was carried out using the immunosorbent assay of Bioserv Ovari-Antibodi-ELISA for the determination of autoantibodies directed against ovarian antigens in blood serum. This analysis is based on an indirect solid-phase method. Statistical processing was performed using the STATISTICA-5.5 A software package (StatSoft, Inc., USA). The reliability of the difference ( $\mathrm{p}<0,05)$ was determined using Student's t-criterion.

\section{Results AND DISCUSSION}

The average age of women in the study group was not significantly different from the age of the control group patients: $30.4 \pm 0.4$ and $33.6 \pm 0.6$ years, 
Table 1. Indicators of the inflammation in examined women $(\mathrm{M} \pm \mathrm{m})$

\begin{tabular}{|c|c|c|c|c|c|}
\hline & & \multicolumn{4}{|c|}{ Number of Patients } \\
\hline \multirow{2}{*}{\multicolumn{2}{|c|}{ History Data }} & \multicolumn{2}{|c|}{ In the study group, $n=20$} & \multicolumn{2}{|c|}{ In the control group $n=10$} \\
\hline & & abs. & $\%$ & abs. & $\%$ \\
\hline Chronic sa & ingophoritis & 12 & $60 \pm 3.7$ & 2 & $20 \pm 1.2$ \\
\hline \multirow{7}{*}{ TORCH-infections } & Herpes simplex virus & 8 & $40 \pm 1.2$ & - & - \\
\hline & Cytomegalovirus & 7 & $35 \pm 0.9$ & 1 & $10 \pm 0.1$ \\
\hline & Chlamydia & 7 & $35 \pm 0.9$ & - & - \\
\hline & Ureaplasma & 4 & $20 \pm 0.8$ & - & - \\
\hline & Mycoplasma & - & - & - & - \\
\hline & Toxoplasma & 10 & $50 \pm 0.9$ & 1 & $10 \pm 0.1$ \\
\hline & Trichomoniasis & - & - & - & - \\
\hline \multicolumn{2}{|c|}{ Candida Fungi } & 3 & $15 \pm 2.3$ & 1 & $10 \pm 0.1$ \\
\hline
\end{tabular}

Table 2. Level indicators of anti-ovarian antibodies in the examined women

\begin{tabular}{cccc}
\hline Groups of women understudy & $n=$ & Indices of antibody & $p$ \\
\hline Study group & 20 & $4.1 \pm 0.5$ & $<0,05$ \\
\hline Control group & 10 & $7.1 \pm 0.9$ & $>0,05$ \\
\hline
\end{tabular}

Table 3. Indicators of positive and negative results with the IVF of women of the main group

\begin{tabular}{cccccccc}
\hline \multirow{2}{*}{$\begin{array}{c}\text { Subgroups of the main } \\
\text { group }\end{array}$} & $\begin{array}{c}\text { Number of patients } \\
\text { in the group }\end{array}$ & \multicolumn{2}{c}{ Number of pregnancies } & \multicolumn{2}{c}{ Number of failures } & \multicolumn{3}{c}{ Number of unknown results } \\
\cline { 3 - 8 } & 38 & 15 & 39.4 & 16 & 42.1 & 7 & 18.4 \\
\hline $1^{\text {st }}$ subgroup & 20 & 10 & 50.0 & 8 & 40 & 2 & 10.0 \\
\hline $2^{\text {nd }}$ subgroup & 20 & &
\end{tabular}

respectively $(\mathrm{p}>0,05)$. In the study group, the number of women with menstrual irregularities was significantly higher $(53.9 \pm 3.4 \%$ versus $26.9 \pm 2.9 \%)$.

As shown in Table 1, chronic salpingo-oophoritis was diagnosed in 12 women from the study group, which corresponds to $60 \pm 3.7 \%$, whereas in the control group only 2 patients had chronic salpingo-oophoritis, corresponding to $20 \pm 1.2 \%$. Significant prevalence of women with chronic salpingo-oophoritis in the study group indicates the possibility of autoimmune salpingo-oophoritis in this group of patients.

From the history of the TORCH infection study presented in Table 1, in the main group, the Herpes simplex virus was observed in 8 patients $(40 \pm 1.2 \%)$. Cytomegalovirus was detected in 7 patients in the study group (35 $\pm 0.9 \%)$.

7 patients from the study group have been pos-

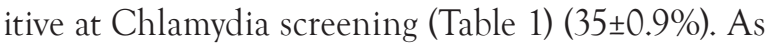
shown in the same table, 4 patients from the study group have been positive for Ureaplasma, corresponding to $20 \pm 0.8 \%$. Mycoplasmosis and Trichomoniasis were not detected in the study group. Toxoplasma was determined in 10 patients $(50 \pm 0.9 \%)$. Candida Fungi were detected in 3 patients from the study group $(15 \pm 2.3 \%)$.
Compared to the control group, the herpes simplex virus was not detected. Cytomegalovirus was detected in one female from the control group $(10 \pm 0.1 \%)$, which is significantly lower compared with the study group. Toxoplasma was detected in one woman from the control group $(10 \pm 0.1 \%), 10$ times less than in the main group. Candida Fungi were found in one woman $(10 \pm 0.1 \%)$, which is 3 times less than in the study group.

The level of anti-ovarian antibodies is shown in Table 2 .

In the control group, the level of anti-ovarian antibodies was $7.1 \pm 0.9$, and in the study group $4.1 \pm 0.5$, which is 1.7 times less than in the control group.

Reduction of the level of anti-ovarian antibodies in patients of the study group was marked by the fact that the obstetric and gynecological history was burdened in this group and manifested as chronic salpingo-oophoritis, artificial abortions, spontaneous abortions, ovarian diseases, including ovarian polycystic syndrome, ovarian-menstrual cycle disorders, curettage of the uterus, oral contraceptives, laparoscopic surgery, repeated stimulation superovulation, which could lead to depletion of the ovaries. Depending on 
Table 4. Results of anti-ovarian antibodies in the examined women $(\mathrm{M} \pm \mathrm{m})$

\begin{tabular}{cccc}
\hline \multirow{2}{*}{ Examination } & \multicolumn{2}{c}{ Antibody } & $p$ \\
\cline { 2 - 3 } & before preparation, $n=20, \mathrm{IU} / \mathrm{ml}$ & after preparation, $n=10, \mathrm{IU} / \mathrm{ml}$ & $>0,05$ \\
\hline $1^{\text {st }}$ subgroup & $4.1 \pm 0.4$ & $4.6 \pm 0.8$ & $>0,05$ \\
\hline $2^{\text {nd }}$ subgroup & $4.1 \pm 0.4$ & $3.2 \pm 0.5$ & \\
\hline $\mathrm{p}$ & $>0,05$ & $>0,05$ & \\
\hline
\end{tabular}

the level of AOA, the functional activity of the ovaries can be assessed.

Plasmapheresis was conducted prior to the in vitro fertilization program. Before and after the plasmapheresis, the level of serum anti-ovarian antibodies in patients with infertility of tubal origin was determined. In the group of women undergoing plasmapheresis, there were women with positive and negative results of IVF (Table 3).

10 women had positive results, representing $50.0 \%$ of all women in the second subgroup. 8 women $(40.0 \%)$ from the second subgroup had negative results. $10.0 \%$ of all patients in the second subgroup were women whose results of artificial insemination were unknown for one reason or another.

A group of patients who did not undergo plasmapheresis consisted of 38 women, who had positive and negative results of artificial insemination. 15 women had positive results, representing 39.4\% of the total number of people in this subgroup. 16 women had negative results, which is $42.1 \%$ of the total number of people in this subgroup. 7 women had unknown results of artificial insemination (18.4\%).

The second subgroup of the main group was represented by women with more burdened obstetric and gynecological history. For example, out of four women with positive results of artificial insemination, two went through the program for the first time, and the other two - repeatedly, twice and three times.

After analyzing the data presented in Table 4, we can see that the first subgroup was made up of patients who had been prepared for IVF, and the second group consisted of patients who had our proposed preparation for IVF with the inclusion of plasmapheresis.

The treatment group consisted of 20 women, with a level of anti-ovarian antibodies of $4.1 \pm 0.4 \mathrm{IU} /$ $\mathrm{ml}$. In the process of preparation for the IVF, the group was divided into 2 subgroups. In subgroup 1, after the traditional preparation for IVF, the level of anti-ovarian antibodies was $4.6 \pm 0.8 \mathrm{IU} / \mathrm{ml}$, which is slightly more than the level of antibodies before the preparation. In 2 subgroups, the level of anti-ovarian antibodies after our proposed preparation with the inclusion of plasmapheresis to IVF was $3.2 \pm 0.5 \mathrm{IU} / \mathrm{ml}$, which is 1.3 times less than before the preparation.
Consequently, after plasmapheresis, the increased level of anti-ovarian antibodies sharply decreases, indicating its effectiveness and the possibility of use in the program for IVF preparation.

\section{Conclusions AND Perspectives of further RESEARCH}

Anti-ovarian antibodies are present in both reproductively healthy women and in patients with infertility. The level of anti-ovarian antibodies can be both increased and reduced, depending on the pathological process that caused infertility. In both cases, this can testify for infertility. After plasmapheresis, the increased level of anti-ovarian antibodies sharply decreases, indicating its effectiveness and the possibility of use in the program for IVF preparation. The obtained results may be the basis for further in-depth, large-scale study of the peculiarities of the development of autoimmune salpingo-oophoritis.

\section{Compliance with Ethics Requirements:}

„The authors declare no conflict of interest regarding this article"

"The authors declare that all the procedures and experiments of this study respect the ethical standards in the Helsinki Declaration of 1975, as revised in 2008(5), as well as the national law. Informed consent was obtained from all the patients included in the study"

„No funding for this study"

\section{References}

1. Baird DT, G. Benagiano G, Cohen J. Physiopathological determinants of human infertility. Human Reproduction Update 2002; 8(5): 435-447.

2. Chilcott IT, Margara R, Cohen H. Pregnancy outcome is not affected by antiphospholipid antibody status in women referred for in vitro fertilization. Fertility and Sterility 2000;73(3): 526-530.

3. Gleicher N. Antiphospholipid antibodies (aPL) affect in vitro fertilization (IVF) outcome. American Journal of Reproductive Immunology 2001;46(5):330-331.

4. Byersdorfer CA, Schweitzer GG, Unanue ER. Diabetes is predicted by the $\beta$ cell level of autoantigen. Journal of Immunology 2005;175(7):4347-4354. 
5. Forges T, Monnier-Barbarino P, Faure GC, Béné MC. Autoimmunity and antigenic targets in ovarian pathology. Human Reproduction Update 2004;10(2):163-175.

6. Bats AS, Barbarino PM, Bene MC, Faure GC, Forges T. Local lymphocytic and epithelial activation in a case of autoimmune oophoritis. Fertility and Sterility 2008;90(3):849 -859.

7. Yan G, Schoenfeld D, Penney C, Hurxthal K, Taylor AE, Faustman D. Identification of premature ovarian failure patients with underlying autoimmunity. Journal of Women's Health and Gender-Based Medicine 2000;9(3):275-287.

8. Crosignani PG, Rubin BL. Optimal use of infertility diagnostic tests and treatments. The ESHRE Capri Workshop Group. Human Reproduction 2000; 15 (3), 723-732.

9. Kelkar RL, Meherji PK, Kadam SS, Gupta SK, Nandedkar TD. Circulating auto-antibodies against the zona pellucida and thyroid microsomal antigen in women with premature ovarian failure. Journal of Reproductive Immunology 2005; 66 (1): 53-67.

10. Rodgers AK, Wang J, Zhang Y. Association of tubal factor infertility with elevated antibodies to Chlamydia trachomatis caseinolytic protease P. American Journal of Obstetrics and Gynecology 2010;203(5):484-494.

11. Sarapik A, Haller-Kikkatalo K, Utt M, Teesalu K, Salumets A, Uibo R. Serum anti-endometrial antibodies in infertile women potential risk factor for implantation failure. American Journal of Reproductive Immunology 2010;63(5):49-357.

12. Altmäe S, Martínez-Conejero JA, Salumets A. Endometrial gene expression analysis at the time of embryo implantation in women with unexplained infertility. Molecular Human Reproduction 2010;16(3):178-187.

13. Altmäe S, Salumets A, Bjuresten K. Tissue factor and tissue factor pathway inhibitors TFPI and TFPI2 in human secretory endometrium-possible link to female infertility. Reproductive Sciences 2011;18(7):666-678

14. Altmäe S, Stavreus-Evers A, Ruiz JR. Variations in folate pathway genes are associated with unexplained female infertility. Fertility and Sterility 2010;94(1):130-137.

15. Haller K, Sarapik A, Talja I, Salumets A, Uibo R. Controlled ovarian hyperstimulation changes the prevalence of serum autoantibodies in in vitro fertilization patients. American Journal of Reproductive Immunology 2006;56(5):364-370.

16. Jasper MJ, Tremellen KP, Robertson SA. Primary unexplained infertility is associated with reduced expression of the T-regulatory cell transcription factor Foxp3 in endometrial tissue. Molecular Human Reproduction 2006;12(5):301308.

17. Monteleone P, Parrini D, Faviana P. Female infertility related to thyroid autoimmunity: the ovarian follicle hypothesis. American Journal of Reproductive Immunology 2011;66(2):108-114

18. Haller K, Sikut A, Karro H, Uibo R, Salumets A. Circulating anti-follicle-stimulating hormone immunoglobulin A in women: a sperm-prone reaction of mucosal tolerance? Fertility and Sterility 2008;90(4):1253-1255.

19. Edassery SL, Shatavi SV, Kunkel JP. Autoantigens in ovarian autoimmunity associated with unexplained infertility and premature ovarian failure. Fertility and Sterility 2010;94(7):2636-2641
20. Pires ES, Khole VV. A block in the road to fertility: autoantibodies to heat-shock protein $90-\beta$ in human ovarian autoimmunity. Fertility and Sterility 2009;92(4):1395-1409.

21. Turi A, Giannubilo SR, Zanconi S, Mascetti A, Tranquilli AL. Preconception steroid treatment in infertile women with antithyroid autoimmunity undergoing ovarian stimulation and intrauterine insemination: a double-blind, randomized, prospective cohort study. Clinical Therapeutics 2010;32(14):2415-2421.

22. Pires ES, Parikh FR, Mande PV, Uttamchandani SA, Savkar $\mathrm{S}$, Khole VV. Can anti-ovarian antibody testing be useful in an IVF-ET clinic? Journal of Assisted Reproduction and Genetics 2011;28(1):55-64.

23. Pacu I, Ionescu CA, Dimitriu M, Banacu M. Intrauterine insemination in idiopathic infertility. Arch Balk Med Union 2017;51(3):334-339.

24. Santi A, Duarte MMMF, Moresco RN, et al. Association between thyroid hormones, lipids and oxidative stress biomarkers in overt hypothyroidism. Clinical Chemistry and Laboratory Medicine 2010;48(11):1635-1639.

25. Santi A, Duarte MMMF, de Menezes CC, Loro VL. Association of lipids with oxidative stress biomarkers in subclinical hypothyroidism. International Journal of Endocrinology 2012;2012:7.

26. Kelkar RL, Meherji PK, Kadam SS, Gupta SK, Nandedkar TD. Circulating autoantibodies against the zona pellucida and thyroid microsomal antigen in women with premature ovarian failure. J Reprod Immunol 2005; 66: 53-67.

27. Koyama K, Hasegawa A. Premature ovarian failure syndrome may be induced by autoimmune reactions to zona pellucida proteins. J Reprod Endokrinol 2006;3: 94-97.

28. Luborsky J. Ovarian autoimmune disease and ovarian autoantibodies. J Womens Health Gend Based Med 2002;11: 585-599.

29. Monnier-Barbarino P, Jouan C, Dubois M, Gobert B, Faure G, Béne MC. Anti-ovarian antibodies and in vitro fertilization: cause or consequence? Gynecol Obstet Fertil 2003;31:770-773.

30. Novosad JA, Kalantaridou SN, Tong ZB, Nelson LM. Ovarian antibodies as detected by indirect immunofluorescence are unreliable in the diagnosis of autoimmune premature ovarian failure: a controlled evaluation. BMC Womens Health 2003;3:2.

31. Pires ES, Parte PP, Meherji PK, Khan SA, Khole VV. Naturally occurring anti-albumin antibodies are responsible for false positivity in diagnosis of autoimmune premature ovarian failure. J Histochem Cytochem 2006;54:397-405.

32. Yan G, Schoenfeld D, Penney C, Hurxthal K, Taylor AE, Faustman D. Identification of premature ovarian failure patients with underlying autoimmunity. J Womens Health Gend Based Med 2000;9: 275-287.

33. Taylor AE. Systemic adversities of ovarian failure. J Soc Gynecol Investig 2001; 8: S7-S9.

34. Johnson J, Canning J, Kaneko T, Pru SK, Tilly JL. Germline stem cells and follicular renewal in the postnatal mammalian ovary. Nature 2004:428:145-50.

35. Byskof AG, Faddy MJ, Lemmen JG, Andersen CY. Eggs forever? Differentiation 2005;73:438-46. 